\title{
Derivation of Indicators for Value Assessment of School Gardens
}

\author{
In-Kyoung Hong, Hyung-Kwon Yun*, Young-Bin Jung, and Sang-Mi Lee \\ Researcher, Urban Agriculture Research Division, National Institute of Horticultural and Herbal Science, Wanju 55365, Korea
}

\section{ABSTRACT}

Background and objective: The boom in urban agriculture has also resulted in the creation of many school gardens. With the increase in various hands-on education programs, people are interested in assessing the value of school gardens. This study was conducted to derive indicators for service value assessement of educational farming experience using school gardens.

Methods: Through literature review, we selected assessment items and sub-factors. The indicators for evaluating the effectiveness of school gardens are classified using the Delphi method that involve a focus group experts. In order to increase the reliability and validity of the selected and classified items, an exploratory factor analysis was conducted. In addition, the relative importance and priority of each factor in each field were assessed using the analytic hierarchy process (AHP).

Results: We classified the indicators into 4 criteria and come up with 13 items and 33 sub-factors in educational value, health value, economic value, and ecological and environmental value. Most of the items for the 4 value criteria derived were significant for assessing the value of agricultural experience services with content validity ratio (CVR) higher than 0.59 and reliability higher than .6. In the value criteria, the experts rated educational value as the most important, followed by health value, ecological and environmental value, and economic value. In the assessment items, the most important was improvement of social functions. In the sub-factors, the most important was strengthening of ties (friendly interactions). Conclusion: Among the derived indicators assessing the value of school gardens, 4 criteria, 12 evaluation items and 29 sub-factors showed significance. The schematic index would be useful for the assessment.

Keywords: alternative selection, analytic hierarchy process, relative assessment, statistical significance, urban agriculture

\section{Introduction}

School gardens are created using boxes or open grounds within or near schools, adopting various educational programs for students to promote understanding of food and natural circulation in the process of actually growing and harvesting crops and to recover not only physical and mental health but also sensitivity about life and nature (Jang and Oh, 2012). These school gardens are farms, practical training sites or spaces made in school to grow plants and animals required for education so that students can observe them. They are receiving attention as part of agricultural experience through student gardening, and multiple values of school gardens are rising significantly with the increase of gardens and various experience-based programs on the school grounds due to activation of urban agriculture (Jang, 2016).

Forming school gardens for education is included in the detailed strategies for space expansion in the 5-year plan (1st) to promote urban agriculture by the Ministry of Agriculture, Food and Rural Affairs. It was carried out as the 'School Farm' Formation Project (2015-2018) to secure practical spaces for Seoul Urban Agriculture 2.0 Masterplan (Seoul Economic Promotion Headquarters, 2015). For a long time, the U.S., U.K. and Japan have been aware of the importance of inclusive education connected to other fields of study as well as healthy growth and development of students through school garden activities, and thus are actively using school gardens (Jang et al., 2017). School

This study is supported by the Rural Development Administration's project (PJ01364403).

Received: June 20, 2020, Revised: July 17, 2020, Accepted: July 20, 2020

First author: In Kyoung Hong, inkyoung63@korea.kr, (1) https://orcid.org/0000-0002-7050-5413

*Corresponding author: Hyung Kwon Yun, yun0309@korea.kr, (1) https://orcid.org/0000-0001-9973-4706 
gardens are also increasing in Korea as well, with the support of the central and local governments to provide environmental and food life education and vitalize urban agriculture (Jang and Oh, 2012). As such, school gardens are established as spaces that are small yet useful in carrying out various experiences and activities related to urban agriculture for students in the city that lacks greens. School garden activities had psychological effects on students such as increase in environmental susceptibility and change in positive emotions (Hazzard et al., 2011; Kim et al., 2007; Paek, 2012). Moreover, from the perspective of preservation of urban environment, school gardens served as farmlands in the city despite their small sizes, performing various functions such as absorbing rainwater, promoting circulation, preventing urban heat island, and purifying air (Kang et al., 2007). In other words, they include values beyond just farming activities, such as protection and restoration of the urban environment, leisure activities, ecological education, and community revitalization based on agriculture, and thus are important in terms of a healthy ecological environment by providing habitats for living things in the city that lacks greens. Therefore, it is necessary to continuously expand school garden education as a space to change the environmental awareness and attitude of the growing future generations. However, studies on school gardens thus far were limited to analysis on the current state of school gardens in metropolitan areas (Ansan Urban Agricultural Coalition, 2015; Jang and Oh, 2012; Paek, 2012; Lee et al., 2018) and educational functions, emotional and psychological changes (Cotugna et al., 2012; Hong and Kim, 2017; Kwack and Park, 2017; Rural Development Administration[RDA], 2013; Yun et al., 2018), and none of them analyzed comprehensive and objective service values of agricultural experience in terms of health, economy and ecological environment.
This study is to objectively assess service values of educational farming experience using school gardens based on previous studies that analyzed the current state of school gardens (Chae et al., 2019; Jang et al., 2017) and use the results as the data to establish more efficient school garden policies. The purpose is to derive value assessment indicators for school gardens by selecting initial items to assess the effects of school gardens based on literature review and having them reviewed by a focus group of experts (Fig. 1).

\section{Research Methods}

\section{Details}

To derive service value assessment indicators of educational farming experience using school gardens, this study adopted scale development or assessment item development as a socio-scientific research method. This is used when quantitative measurement cannot be used to measure the concepts of research subjects or when there is a need for a quantitative approach of complex research subjects. It is a methodological approach for multiple items instead of single items, revealing cognitive and conceptual views. Thus, the developed scales are logically, empirically and organically correlated in the assessment system (Song, 2018). DeVellis (2003) mentioned that, initial items extracted and constructed through prior research in the process of scale development are important as they secure theoretical grounds, and they increase reliability of the theoretical background in the review process of experts in related fields. To select assessment items for service values of school gardens, this study entered keywords such as school garden, agriculture for education, service value assessment

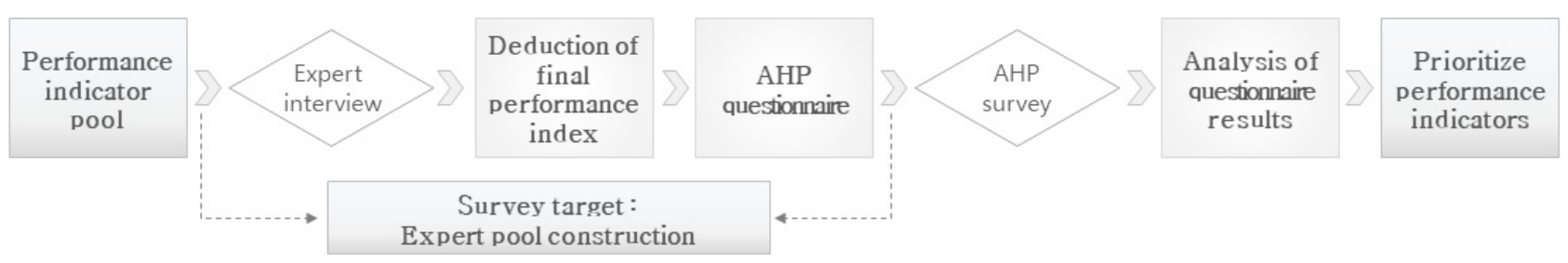

Fig. 1. Research process. 
of farming experience, etc. on the RISS search site of Korea Education \& Research Information Service (KERIS). Out of total 1,019 research articles, we collected eight full text articles of service value assessment research data similar to this study and selected service assessment items and sub-factors (Table 1).

\section{Subjects and methods}

The Delphi method requires a panel of at least 10 persons to minimize errors of the small group of experts and maximize the group's reliability (Anderson, 1997; Ewing, 1991). This study organized the focus group with total 11 experts who have experience participating in research related to school gardens, are public officials working in public institutions related academically or practically to school gardens, or are involved in the academia or relevant research (Table 2).

We gathered and revised the opinions of experts through focus group interviews in the National Institute of Horticultural and Herbal Science located in Wanju-gun, Jeollabuk-do on October 4, 2019. We applied an expert survey technique to ensure validity of the assessment items and indicators and collect other opinions. After rating the suitability and validity of structured survey items on a 5-point Likert scale, we had the experts provide other opinions. The survey in the Delphi method was conducted twice from November 10 to 25,2019 in the order of items and sub-items for service value assessment of school garden farming experiences. In case the items are invalid or not convergent based on the assessment criteria, other opinions were reviewed and supplemented to conduct a re-survey as an additional round. Collected data were analyzed using SPSS for Windows 25.0 and Excel by setting the hierarchical structure of each item. We verified validity and reliability based on content validity ratio (CVR). Items are considered to have content validity if the values are higher than the minimum value of CVR according to the number of panels as shown in

Table 1. List of selected research articles for collection of assessment items

\begin{tabular}{|c|c|c|c|c|}
\hline No & Title & Author & Year & Research type \\
\hline 1 & $\begin{array}{l}\text { A study on ecosystem services evaluation and promotional plan for the } \\
\text { activation of the school farm }\end{array}$ & Jang, J. & 2016 & Doctoral dissertation \\
\hline 2 & $\begin{array}{l}\text { A study on evaluating the diverse value of urban agriculture and its } \\
\text { activation plan }\end{array}$ & Lee, W.S. & 2017 & Doctoral dissertation \\
\hline 3 & A study on exploring an order of priority in urban agricultural policies & Ji, T.G. & 2011 & Doctoral dissertation \\
\hline 4 & $\begin{array}{l}\text { Development of evaluation indicators for performance improvement of } \\
\text { horticultural therapy garden }\end{array}$ & Ahn, J.J. & 2018 & Doctoral dissertation \\
\hline 5 & $\begin{array}{l}\text { Important distance education practices: A Delphi study of administrators } \\
\text { and coordinators of distance education programs in higher education }\end{array}$ & Anderson, E.T. & 1997 & Doctoral dissertation \\
\hline 6 & $\begin{array}{l}\text { Needs analysis of experiential learning program for eco-friendly school } \\
\text { farm activation-target of teachers in elementary school }\end{array}$ & Jang, J. and C.H. Oh & 2012 & J. Org. Agric. \\
\hline 7 & $\begin{array}{l}\text { Set up and running status of school gardening at elementary schools: } \\
\text { Focus on Jeollabuk-do }\end{array}$ & Jang, Y. et al. & 2017 & $\begin{array}{l}\text { Korean J. Community } \\
\text { Living Sci. }\end{array}$ \\
\hline 8 & The study on school farm for experiential education in primary school & $\begin{array}{l}\text { Rural Development } \\
\text { Administration }\end{array}$ & 2013 & Completion report \\
\hline
\end{tabular}

Table 2. Composition of expert focus group

\begin{tabular}{cccccc}
\hline Field & Participants & Affiliation & Career years & Task & Education and advisory committee \\
\hline Academia & 3 & University & $10-20$ & Person in charge of the relevant affairs concerned & 27.3 \\
Research & 3 & Research institute & $7-15$ & Performing related tasks & 45.4 \\
Public official & 5 & Government & $10-15$ & & 100.0 \\
Total & 11 & & & & \\
\hline
\end{tabular}


Table 3. Minimum values of content validity ratio

\begin{tabular}{ccccccccccccc}
\hline Number of panelists & 10 & 11 & 12 & 13 & 14 & 15 & 20 & 25 & 30 & 35 & 40 \\
\hline Minimum value & 0.62 & 0.59 & 0.56 & 0.54 & 0.51 & 0.49 & 0.42 & 0.37 & 0.33 & 0.31 & 0.29 \\
\hline
\end{tabular}

Note. Adapted from “A quantitative approach to content validity”, by C.H. Lawshe, 1975, Personnel Psychology, 28 , p. 568.

Table 3 (Lawshe, 1975).

We calculated Cronbach's $\alpha$ to determine internal consistency of the assessment items derived by examining whether the experts responded with stability and consistency. Finally, we presented the importance according to weights among factors as well as priorities of assessment indicators for each item through pairwise comparison between alternatives of the analytic hierarchy process (AHP).

\section{Results and Discussion}

\section{Selection of assessment items for service values of school gardens}

To derive the assessment method for service values of school gardens, we selected 13 assessment items and 33 sub-items in four school garden values (education, health, economy, ecology and environment) using the Delphi method that involves experts. Educational value had items such as $\mathrm{x} 1$ (improvement of social functions), $\mathrm{x} 2$ (improvement in academic achievement), $\mathrm{x} 3$ (promotion of agricultural awareness), X4 (community revitalization); health value had items such as $\mathrm{x} 5$ (promotion of physical health), $\mathrm{x} 6$ (improvement of eating habits), $x 7$ (promotion of mental health); economic value had items such as $\mathrm{x} 8$ (future value improvement of agricultural products), $\mathrm{x} 9$ (job creation), x10 (revitalization of economy); and ecological and environmental value had items such as x11 (improvement of the climatic environment), x12 (ecological service), x13 (landscape beautification; Table 4).

\section{Content validity and reliability testing of the scale}

\section{Validity testing}

The index to determine content validity is estimated by the correlation coefficient (Kwon, 2008). The panel in this study is comprised of 11 experts, and thus validity is proved if it is higher than the minimum CVR of 0.59 based on Lawshe (1975). However, y4 (improvement in academic interest) and y5 (improvement of concentration) of $\mathrm{x} 2$ (improvement in academic achievement) in educational value, y13 (improvement in obesity rate) of $\mathrm{x} 5$ (promotion of physical health) in health value, and y23 (raising awareness on food production) of $\mathrm{x} 8$ (future value improvement of agricultural products) in economic value had CVR below 0.59 and thus were eliminated as content validity was not proved. Other items all had CVR higher than 0.59 and thus their content validity was proved (Table 5).

\section{Reliability testing}

We calculated Cronbach's $\alpha$ to determine internal consistency of the assessment items derived by examining whether the experts responded with stability and consistency. As a result of analyzing reliability, all items showed .6 or higher as shown in Table 6, ensuring reliability of items for service value assessment. Kang (2016) claimed that items are reliable of the Cronbach's $\alpha$ is at least .5 , which indicates that assessment items for school garden service values are well structured.

\section{Relative importance and priority of factors through AHP}

\section{Relative importance and prionity of values}

As for relative importance and priority of values, relative importance weights were calculated in the order of 'educational value'(.546), 'health value'(.223), 'ecological and environmental value'(.136), 'economic value'(.095). Lee (2017) claimed that items have consistency if consistency ratio (CR) is less than $10 \%$. Here, the consistency index among superordinate attributes was less than .1, thereby proving significance (Table 7). This is different from the report by RDA (2013) in which environmental value was evaluated to have most importance. However, 
Table 4. Evaluation items and sub-factors for value assessment of school garden

\begin{tabular}{|c|c|c|c|c|}
\hline \multirow{2}{*}{ Value } & \multicolumn{2}{|r|}{ Evaluation item } & \multicolumn{2}{|r|}{ Sub-factor } \\
\hline & No & Item & No & Item \\
\hline \multirow{9}{*}{$\begin{array}{l}\text { Educational } \\
\text { value }\end{array}$} & \multirow{3}{*}{$\mathrm{x} 1$} & \multirow{3}{*}{$\begin{array}{l}\text { Improvement of } \\
\text { social functions }\end{array}$} & $\mathrm{y} 1$ & Awareness of social existence \\
\hline & & & $\mathrm{y} 2$ & Expansion of interactions \\
\hline & & & y3 & Improvment of communication skills \\
\hline & \multirow{2}{*}{$\mathrm{x} 2$} & \multirow{2}{*}{$\begin{array}{l}\text { Improvement in academic } \\
\text { achievement }\end{array}$} & $\mathrm{y} 4$ & Improvement in academic interest \\
\hline & & & y5 & Improvement of concentration \\
\hline & \multirow{2}{*}{$\mathrm{x} 3$} & \multirow{2}{*}{$\begin{array}{l}\text { Promotion of agricultural } \\
\text { awareness }\end{array}$} & y6 & Awareness of the relationship between agriculture and humans \\
\hline & & & y7 & Awareness of the relationship between agriculture and ecosystems \\
\hline & \multirow{2}{*}{$\mathrm{x} 4$} & \multirow{2}{*}{ Community revitalization } & y8 & Community formation and recovery \\
\hline & & & y9 & Strengthening of ties (friendly interactions) \\
\hline \multirow{11}{*}{$\begin{array}{l}\text { Health } \\
\text { value }\end{array}$} & \multirow{4}{*}{$\mathrm{x} 5$} & \multirow{4}{*}{ Promotion of physical health } & y10 & Provision of place for activities \\
\hline & & & y11 & Provision of opportunities for exercise \\
\hline & & & y12 & Increase of physical activities \\
\hline & & & y13 & Improvement in obesity rate \\
\hline & \multirow{3}{*}{ x6 } & \multirow{3}{*}{ Improvement of eating habits } & y14 & Improvement of plant friendliness \\
\hline & & & y15 & Understanding of food use effects \\
\hline & & & y16 & Improvement in unbalanced diet \\
\hline & \multirow{4}{*}{$\mathrm{x} 7$} & \multirow{4}{*}{ Promotion of mental health } & $\mathrm{y} 17$ & Subjective well-being \\
\hline & & & y18 & Improvement of self-esteem \\
\hline & & & y19 & Improvement of satisfaction \\
\hline & & & y20 & Emotional development \\
\hline \multirow{7}{*}{$\begin{array}{l}\text { Economic } \\
\text { value }\end{array}$} & \multirow{3}{*}{$\mathrm{x} 8$} & \multirow{3}{*}{$\begin{array}{l}\text { Future value improvement of } \\
\text { agricultural products }\end{array}$} & y21 & Securing future consumers \\
\hline & & & y22 & Raising awareness on the value of agricultural products \\
\hline & & & y23 & Raising awareness on food production \\
\hline & \multirow{2}{*}{$\mathrm{x} 9$} & \multirow{2}{*}{ Job creation } & y24 & Development of materials related to formation and management \\
\hline & & & y 25 & Increased number of related job and active personnel \\
\hline & \multirow{2}{*}{$\mathrm{x} 10$} & \multirow{2}{*}{ Revitalization of economy } & y26 & Revitalization of school garden formation \\
\hline & & & y 27 & Revitalization of garden farming materials industry \\
\hline \multirow{6}{*}{$\begin{array}{c}\text { Ecological \& } \\
\text { environmental } \\
\text { value }\end{array}$} & \multirow{2}{*}{$\mathrm{x} 11$} & \multirow{2}{*}{$\begin{array}{l}\text { Improvement of climate } \\
\text { environment }\end{array}$} & y28 & Environmental regulation \\
\hline & & & y29 & Natural experience and environmental education \\
\hline & v12 & Ecolonicol service & $\mathrm{y} 30$ & Improvement of biodiversity \\
\hline & & Leviogital Setviet & $\mathrm{y} 31$ & Improvment of resources (soil, air, water) \\
\hline & $\mathrm{x} 13$ & I andcone heoutification & $\mathrm{y} 32$ & Improvement of landscape \\
\hline & X15 & Landscape deautnination & y33 & Utilization and consumption of various resources \\
\hline
\end{tabular}

the result was consistent in terms of significance as the consistency index among attributes such as cognitive, emotional, social, physical/behavioral, environmental and economic effects of school gardens was all below 0.1. This was also different from the result by Lee (2017) who eval- uated sociocultural value as top priority in terms of multiple values of urban agriculture. This may be due to the implicative meaning of "school" and expression of change to increase the effect of educational use in group life. 
Table 5. Content validity ratio (CVR) of evaluation items and sub factors for value assessment of school garden

\begin{tabular}{|c|c|c|c|c|c|}
\hline Value & $\begin{array}{c}\text { Evaluation } \\
\text { item }^{\mathrm{z}}\end{array}$ & Sub-factor ${ }^{\mathrm{y}}$ & M & $\mathrm{SD}$ & CVR \\
\hline \multirow{9}{*}{$\begin{array}{l}\text { Educational } \\
\text { value }\end{array}$} & \multirow{3}{*}{$\mathrm{x} 1$} & y1 & 4.31 & 0.751 & 0.69 \\
\hline & & y2 & 4.54 & 0.519 & 1.00 \\
\hline & & y3 & 4.23 & 0.725 & 0.69 \\
\hline & \multirow{2}{*}{$\mathrm{x} 2$} & $\mathrm{y} 4$ & 3.77 & 0.725 & 0.54 \\
\hline & & y5 & 3.85 & 0.801 & 0.54 \\
\hline & \multirow{2}{*}{$\mathrm{x} 3$} & y6 & 4.23 & 0.725 & 0.69 \\
\hline & & y7 & 4.31 & 0.751 & 0.69 \\
\hline & \multirow{2}{*}{$\mathrm{x} 4$} & y8 & 4.46 & 0.660 & 0.85 \\
\hline & & y9 & 4.38 & 0.650 & 0.85 \\
\hline \multirow{11}{*}{$\begin{array}{l}\text { Health } \\
\text { value }\end{array}$} & \multirow{4}{*}{$x 5$} & y10 & 4.46 & 0.660 & 0.85 \\
\hline & & y11 & 4.08 & 0.760 & 0.59 \\
\hline & & y12 & 4.08 & 0.862 & 0.69 \\
\hline & & y13 & 3.69 & 0.855 & 0.54 \\
\hline & \multirow{3}{*}{$x 6$} & y14 & 4.69 & 0.630 & 0.85 \\
\hline & & y15 & 4.00 & 0.707 & 0.59 \\
\hline & & y16 & 4.00 & 0.707 & 0.59 \\
\hline & \multirow{4}{*}{$x 7$} & y17 & 4.31 & 0.855 & 0.85 \\
\hline & & y18 & 4.38 & 0.650 & 0.85 \\
\hline & & y19 & 4.46 & 0.660 & 0.85 \\
\hline & & y20 & 4.62 & 0.506 & 1.00 \\
\hline \multirow{7}{*}{$\begin{array}{l}\text { Economic } \\
\text { value }\end{array}$} & \multirow{3}{*}{$\mathrm{x} 8$} & y21 & 4.00 & 0.707 & 0.59 \\
\hline & & $\mathrm{y} 22$ & 4.15 & 0.555 & 0.85 \\
\hline & & y23 & 3.85 & 0.801 & 0.54 \\
\hline & \multirow{2}{*}{$\mathrm{x} 9$} & y24 & 3.77 & 0.832 & 0.69 \\
\hline & & y25 & 3.62 & 1.193 & 0.59 \\
\hline & \multirow{2}{*}{$\mathrm{x} 10$} & y26 & 4.08 & 0.760 & 0.85 \\
\hline & & y27 & 3.85 & 0.689 & 0.69 \\
\hline \multirow{6}{*}{$\begin{array}{l}\text { Ecological \& } \\
\text { environmental } \\
\text { value }\end{array}$} & \multirow{2}{*}{$\mathrm{x} 11$} & y28 & 3.62 & 0.768 & 0.59 \\
\hline & & y29 & 4.15 & 0.899 & 0.69 \\
\hline & \multirow{2}{*}{$\mathrm{x} 12$} & y30 & 3.77 & 0.927 & 0.59 \\
\hline & & y31 & 4.00 & 1.000 & 0.69 \\
\hline & \multirow{2}{*}{ x13 } & y32 & 4.31 & 0.751 & 0.69 \\
\hline & & y33 & 3.92 & 0.494 & 0.69 \\
\hline
\end{tabular}

${ }^{\mathrm{z}}$ Evaluation items, ${ }^{\mathrm{y}}$ Sub-factor were derived from Table 4.

\section{Relative importance and priority of assessment items} of values

(1) Relative importance and priority of each assessment item

As for relative importance and priority of educational
Table 6. Reliability analysis of evaluation items for value assessment of school garden

\begin{tabular}{|c|c|c|c|}
\hline Value & $\begin{array}{c}\text { Evaluation } \\
\text { item }^{\mathrm{z}}\end{array}$ & $\begin{array}{c}\text { Number of } \\
\text { sub-items }\end{array}$ & Cronbach's $\alpha$ \\
\hline \multirow{3}{*}{$\begin{array}{l}\text { Educational } \\
\text { value }\end{array}$} & $\mathrm{x} 1$ & 3 & .800 \\
\hline & $\mathrm{x} 3$ & 2 & .768 \\
\hline & $\mathrm{x} 4$ & 2 & .686 \\
\hline \multirow{3}{*}{ Health value } & $\mathrm{x} 5$ & 3 & .885 \\
\hline & $x 6$ & 3 & .732 \\
\hline & $\mathrm{x} 7$ & 4 & .874 \\
\hline \multirow{3}{*}{ Economic value } & $\mathrm{x} 8$ & 3 & .733 \\
\hline & x9 & 2 & .764 \\
\hline & $\mathrm{x} 10$ & 2 & .794 \\
\hline \multirow{3}{*}{$\begin{array}{c}\text { Ecological and } \\
\text { environmental } \\
\text { value }\end{array}$} & $\mathrm{x} 11$ & 2 & .725 \\
\hline & $\mathrm{x} 12$ & 2 & .835 \\
\hline & $\mathrm{x} 13$ & 2 & .645 \\
\hline
\end{tabular}

${ }^{\mathrm{z}}$ Evaluation items were derived from Table 4.

Table 7. Relative importance and priority of the value factors

\begin{tabular}{ccc}
\hline Value & $\begin{array}{c}\text { Relative } \\
\text { importance weight }\end{array}$ & Rank \\
\hline Educational value & .546 & 1 \\
Health value & .223 & 2 \\
Economic value & .095 & 4 \\
Ecological and environmental value & .136 & 3 \\
\hline Consistency ratio (CR) & 0.003 & \\
\hline
\end{tabular}

value assessment items, importance was given in the order of $\mathrm{x} 1$ (improvement of social functions), $\mathrm{x} 4$ (community revitalization), $\mathrm{x} 3$ (promotion of agricultural awareness. Health value had importance in the order of $x 7$ (promotion of mental health), x5 (promotion of physical health), x6(improvement of eating habits). Economic value had importance in the order of $\mathrm{x} 8$ (future value improvement of agricultural products), x10 (revitalization of economy), x9 (job creation), while ecological and environmental value had importance in the order of x13 (landscape beautification), x11 (improvement of the climatic environment), x12 (ecological service). All had consistency with CR lower than 0.1 (Table 8). Economic value had the same result as Lee (2017), but ecological and environmental value showed a different result from Lee (2017) in which preservation of the ecosystem was most important. 
Table 8. Relative importance and priority of evaluation items by each value

\begin{tabular}{|c|c|c|c|c|c|c|c|}
\hline Value & $\begin{array}{c}\text { Evaluation } \\
\text { item }^{\mathrm{z}}\end{array}$ & $\begin{array}{c}\text { Relative } \\
\text { importance } \\
\text { weight }\end{array}$ & Rank & Value & $\begin{array}{c}\text { Evaluation } \\
\text { item }^{\mathrm{z}}\end{array}$ & $\begin{array}{c}\text { Relative } \\
\text { importance } \\
\text { weight }\end{array}$ & Rank \\
\hline \multirow{4}{*}{ Education } & $\mathrm{x} 1$ & .393 & 1 & \multirow{3}{*}{ Economic } & $\mathrm{x} 8$ & .576 & 1 \\
\hline & $\mathrm{x} 3$ & .232 & 3 & & $\mathrm{x} 9$ & .209 & 3 \\
\hline & $\mathrm{x} 4$ & .279 & 2 & & $\mathrm{x} 10$ & .215 & 2 \\
\hline & & & CR 0.003 & & & & CR 0.000 \\
\hline \multirow{3}{*}{ Health } & $\mathrm{x} 5$ & .295 & 2 & \multirow{3}{*}{$\begin{array}{l}\text { Ecological \& } \\
\text { environment }\end{array}$} & x11 & .293 & 2 \\
\hline & $x 6$ & .244 & 3 & & $\mathrm{x} 12$ & .292 & 3 \\
\hline & $\mathrm{x} 7$ & .461 & 1 & & $\mathrm{x} 13$ & .425 & 1 \\
\hline & & & CR 0.000 & & & & CR 0.000 \\
\hline
\end{tabular}

Note. $\mathrm{CR}=$ consistency ratio.

${ }^{\mathrm{z}}$ Evaluation items were derived from Table 4.

(2) Overall relative importance and priority of assessment items

As for relative importance and priority of all assessment items considering the values, there was high importance in the order of $\mathrm{x} 1$ (improvement of social functions), $\mathrm{x} 4$ (community revitalization), $\mathrm{x} 3$ (promotion of agricultural awareness), $x 7$ (promotion of mental health), $x 5$ (promotion of physical health), x13 (landscape beautification; Table 9). This is different from Lee (2017) that assessed the value of urban agriculture, which may be due to the difference in the limited space of "school" as well as limited subjects and the purpose of education.

\section{Relative importance and priority of sub-factors}

(1) Relative importance and priority by sub-factor of each assessment item

As for relative importance and priority of improvement of social functions, there was high importance in the order of y2 (expansion of interactions), y3 (improvement of communication skills), y1 (awareness of social existence). Promotion of agricultural awareness had importance in the order of y6 (awareness of the relationship between agriculture and humans), y7 (awareness of the relationship between agriculture and ecosystems). Community revitalization had importance in the order of y9 (strengthening of ties [friendly interactions]), y8 (community formation and recovery). Consistency was secured with CR lower than 0.1 (Table 10).
Table 9. Overall relative importance and priority of evaluation items

\begin{tabular}{ccc}
\hline Evaluation $^{\text {item }}{ }^{\mathrm{z}}$ & Relative importance weight & Rank \\
\hline x1 & .214 & 1 \\
x3 & .127 & 3 \\
x4 & .153 & 2 \\
x5 & .066 & 5 \\
x6 & .054 & 8 \\
x7 & .103 & 4 \\
x8 & .055 & 7 \\
x9 & .020 & 12 \\
x10 & .020 & 11 \\
x11 & .040 & 9 \\
x12 & .038 & 10 \\
x13 & .058 & 6 \\
\hline
\end{tabular}

${ }^{\mathrm{z}}$ Evaluation items were derived from Table 4.

As for relative importance and priority of promotion of physical health, there was high importance in the order of y10 (provision of place for activities), y12 (increase of physical activities), y11 (provision of opportunities for indoor and outdoor exercises). Improvement of eating habits had importance in the order of y14 (improvement of plant friendliness), y15 (understanding of food use effects), y16 (improvement in unbalanced diet). Promotion of mental health had importance in the order of y20 (emotional development), y19 (improvement of satisfaction), y18 (improvement of self-esteem), y17 (subjective well-being). Consistency was secured with CR lower than 0.1 (Table 10). 
Table 10. Relative importance and priority of sub-factors by each evaluation item

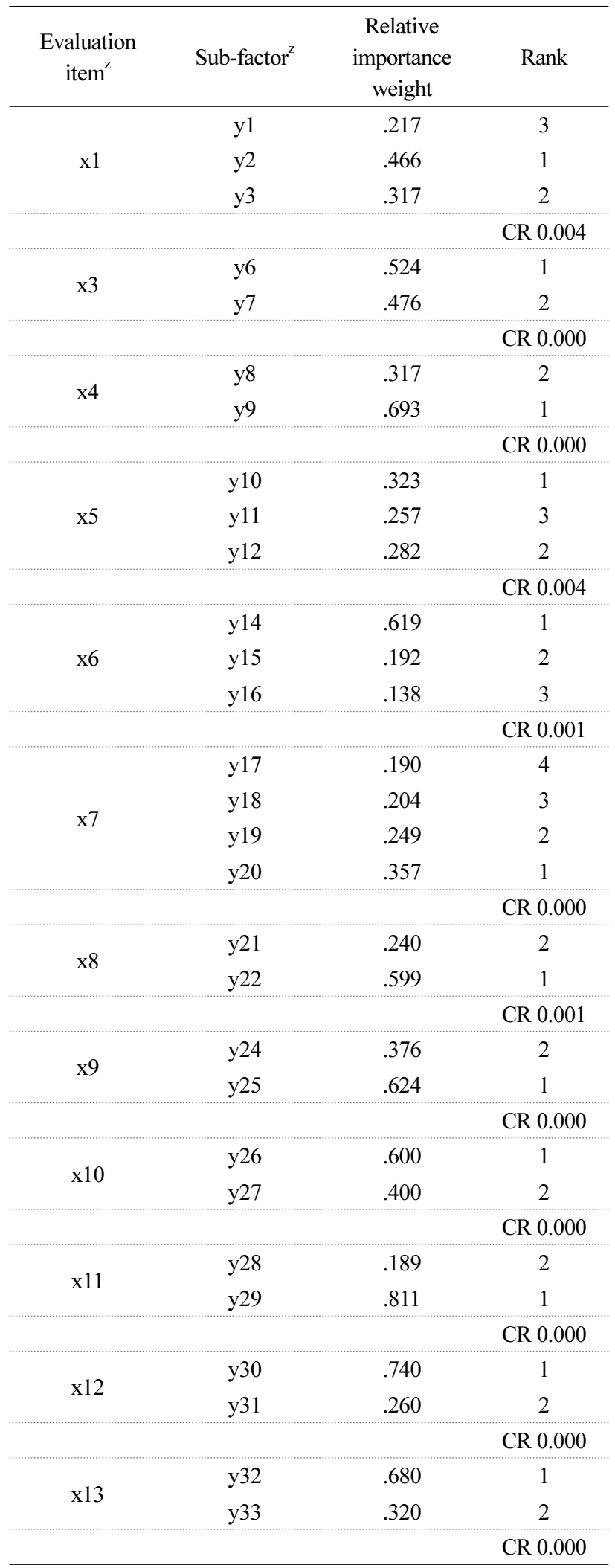

Note. $\mathrm{CR}=$ consistency ratio.

${ }^{\mathrm{z}}$ Evaluation items, ${ }^{\mathrm{y}} \mathrm{Sub}$-factor were derived from Table 4.
As for relative importance and priority of promotion of future value improvement of agricultural products, there was high importance in the order of y22 (raising awareness on the value of agricultural products), y21 (securing future consumers). Job creation had importance in the order of y25 (increase in related jobs and active personnel), y24 (development of materials related to formation and management). Revitalization of economy had importance in the order of y26 (revitalization of school garden formation), y27 (revitalization of the garden farming materials industry). Consistency was secured with $\mathrm{CR}$ lower than 0.1 (Table 10).

As for relative importance and priority of promotion of improvement of the climatic environment, there was high importance in the order of y 29 (natural experience and environmental education), y28 (environmental regulation). Ecological service had importance in the order of y30 (improvement of biodiversity), y31 (improvement of resources [water, soil]). Landscape beautification had importance in the order of y32 (improvement of landscape), y33 (utilization and consumption of various resources). Consistency was secured with CR lower than 0.1 (Table 10).

(2) Overall relative importance and priority of sub-factors

As for overall importance and priority of sub-factors considering values and assessment items, the items had importance in the order of y9 (strengthening of ties [friendly interactions]), y2 (expansion of interactions), y3 (improvement of communication skills), y6 (awareness of the relationship between agriculture and humans), y7 (awareness of the relationship between agriculture and ecosystems), y8 (community formation and recovery), showing that sub-factors of educational value had highest importance (Table 11).

\section{Conclusion}

This study was conducted to derive indicators for service value assessment of educational farming experience using school gardens. We came up with 13 assessment items and 33 sub-items of educational value, health value, economic value, ecological and environmental value using the Delphi 
Table 11. Overall relative importance and priority of sub-factors

\begin{tabular}{|c|c|c|}
\hline Sub-factor ${ }^{\mathrm{z}}$ & Relative importance weight & Rank \\
\hline y1 & .046 & 7 \\
\hline y2 & .100 & 2 \\
\hline $\mathrm{y} 3$ & .068 & 3 \\
\hline y6 & .066 & 4 \\
\hline y7 & .060 & 5 \\
\hline y8 & .048 & 6 \\
\hline y9 & .104 & 1 \\
\hline y10 & .021 & 15 \\
\hline y11 & .017 & 20 \\
\hline y12 & .019 & 18 \\
\hline y14 & .034 & 10 \\
\hline y15 & .010 & 24 \\
\hline y16 & .010 & 25 \\
\hline y17 & .020 & 17 \\
\hline y18 & .021 & 16 \\
\hline y19 & .026 & 14 \\
\hline y20 & .037 & 9 \\
\hline y21 & .013 & 21 \\
\hline y22 & .033 & 11 \\
\hline y24 & .007 & 29 \\
\hline y25 & .012 & 22 \\
\hline y26 & .012 & 23 \\
\hline y27 & .008 & 27 \\
\hline y28 & .008 & 28 \\
\hline y29 & .032 & 12 \\
\hline y30 & .028 & 13 \\
\hline y31 & .010 & 26 \\
\hline y32 & .039 & 8 \\
\hline y33 & .018 & 19 \\
\hline
\end{tabular}

${ }^{\mathrm{z}}$ Sub-factors were derived from Table 4.

method and deriving initial items based on literature review. We also conducted an exploratory factor analysis to increase reliability and validity of the items for development of indicators. The results of assessing relative importance and priority of each factor by field based on pairwise comparison of AHP are as follows.

First, among assessment items based on four values derived, the content validity of all assessment items was higher than CVR 0.59 and reliability higher than .6, excluding improvement of academic interest and improvement of concentration from improvement in academic achievement in educational value, improvement in obesity rate from promotion of physical health in health value, and raising awareness on food production from future value improvement of agricultural products in economic value. Therefore, they were approved as items for service value assessment of farming experience.

Second, educational value was the value that experts considered most important, followed by health value, ecological and environmental value, and economic value. This may be due to the implicative meaning of "school" and expression of change to increase the effect of educational use in group life.

Third, improvement of social functions was considered most important among assessment items, followed by community revitalization, promotion of agricultural awareness, promotion of mental health, promotion of physical health, landscape beautification, future value improvement of agricultural products, improvement of eating habits, improvement in academic achievement, improvement of the climatic environment, ecological service, revitalization of economy, and job creation.

Fourth, strengthening of ties (friendly interactions) was considered most important among sub-factors, followed by expansion of interactions, improvement of communication skills, awareness of the relationship between agriculture and humans, awareness of the relationship between agriculture and ecosystems, community formation and recovery, awareness of social existence, improvement of landscape, emotional development, and improvement of plant friendliness.

This study is an initial-stage research on service value assessment of educational farming experience using school gardens, conducted by selecting a panel of experts in the academia and research circles. Interviews with experts in industrial circles and field specialists are pending due to COVID-19, but will be conducted immediately once the current situation settles down. Formation and use of school gardens are expected to constantly increase due to the social atmosphere, and thus there is an urgent need to establish measures for continuous operation of school gardens and maximization of effects. Based on the results of this study, further research is to be conducted to set detailed criteria for value assessment using a modified Delphi meth- 
od and measure the utility value using the contingent valuation method (CVM) to promote use of school gardens.

\section{References}

Ahn, J.J. 2018. Development of evaluation indicators for performance improvement of horticultural therapy garden. Doctoral dissertation, Jeonbuk National University, Jeonju, Korea.

Anderson, E.T. 1997. Important distance education practices: A Delphi study of administrators and coordinators of distance education programs in higher education. Doctoral dissertation, University of Idaho, United States.

Ansan Urban Agricultural Coalition. 2015. Survey on education of school garden in Ansan area for strengthening hands-on environmental education. Ansan, Korea: Author.

Chae, Y. I.K. Hong, S.M. Lee, Y.B. Jung, and B.K. Lee. 2019. Understanding trends in school gardening and program management. Hortic. Sci. Technol. 37(Suppl. II ):81.

Cotugna, N., C.K. Manning, and J. DiDomentico. 2012. Impact of the use of produce grown in an elementary school garden on consumption of vegetables at school lunch. J. Hunger Environ. Nutr. 7(1):11-19. https://doi.o rg/10.1080/19320248.2012.649668

DeVellis, R.F. 2003. Scale development: Theory and applications (2nd ed.). London: Sage Publications.

Ewing, D.H. 1991. Future competencies needed in the preparation of secretaries in the state of Illinois using the Delphi technique. Doctoral dissertation, University of Iowa, United States.

Hazzard, E.L., E. Moreno, D.L. Beall, and S. Zidenberg-Cher. 2011. Best practices models for implementing, sustaining, and using instructional school gardens in California. J. Nutr. Educ. Behav. 43(5):409-413. https://doi.org/10.10 16/j.jneb.2011.05.005

Hong, U.S. and J.H. Kim. 2017. The effect of the school farm program on the personality of elementary school students. J. Korean Pract. Arts Educ. 23(1):163-186.

Jang, J. 2016. A study on ecosystem services evaluation and promotional plan for the activation of the school farm. Doctoral dissertation, Dongkuk University, Seoul, Korea.
Jang, J. and C.H. Oh. 2012. Needs analysis of experiential learning program for eco-friendly school farm activation: Target of teachers in elementary school. Korean J. Org. Agric. 20(3):283-296.

Jang, Y., S.J. Jeong, K.S. Han, G.M. GIM, I.J. Choi, and J. Heo. 2017. Set up and running status of school gardening at elementary schools: Focus on Jeollabuk-do. Korean J. Community Living Sci. 28(4):613-623. http://doi.org/ 10.7856/kjcls.2017.28.4.613

Ji, T.G. 2011. A study on exploring an order of priority in urban agricultural policies: Using AHP analysis method. Doctoral dissertation, Paichai University, Deajeon, Korea.

Kang, J.H. 2016. Using statistical analysis according to the new spss program. Seoul, Korea: Crownbook Press.

Kang, K.N., J.K. Lee, K.H. Kim, and M.H. Lee. 2007. Revitalization planning of urban farming based on vegetable gardens. J. Inst. Constr. Technol. 26(1):167-176.

Kim, H.D., H.J. Lee, J.W. Choi, G.R. Go, and Y.A. Lee. 2007. The effect of introducing horticultural program to discretionary activity in an elementary school. J. Korean Soc. People Plants Environ. 10(1):50-56.

Kwack, H.R. and H.C. Park. 2017. Adoption of emotional intelligence education in elementary horticulture education and survey of it's recognition to teachers. J. Korean Pract. Arts Educ. 30(1):107-124.

Kwon, T.I. 2008. Study on drawing priority of the influence factors of tourist resort remodeling business: Delphi technic \& analytic hierarchy process. Doctoral dissertation, Sejong University, Seoul, Korea.

Lawshe, C.H. 1975. A quantitative approach to content validity. Pers. Psychol. 28:563-575.

Lee, S.M., Y.N. Jang, Y. Chae, K.S. Han, B.K. Lee, S.J. Jeong, and G.M. Gim. 2018. Survey on the use of farming materials in the elementary school vegetable garden in Jeonbuk area. J. People Plants Environ. 21(6):473-484. https://doi.org/10.11628/ksppe.2018.21.6.473

Lee, W.S. 2017. A study on evaluating the diverse value of urban agriculture and its activation plan. Doctoral dissertation, Seoul National University, Seoul, Korea.

Paek, K.W. 2012. A environmental education plan applying school gardening in the elementary school. Master's thesis, Seoul National University of Education, Seoul, Korea. Rural Development Administration. 2013. The study on 
school farm for experiential education in primary school. Suwon, Korea: Author.

Seoul Economic Promotion Headquarters. 2015. Let's farm in Seoul: Seoul urban agriculture 2.0 master plan(DN-8608). Seoul, Korea: Author.

Song, Y.T. 2018. A study on development of fishing village development project evaluation index from community design point of view. Doctoral dissertation, Chonnam National University, Gwangju, Korea.

Yun, H.S., S.Y. Yun, and B.J. Choi. 2018. Effects of horticultural activities designed to stimulate five senses on the sensory development of children. J. People Plants Environ. 21(5):369-378. https://doi.org/10.11628/ksppe. 2018.21.5.369 